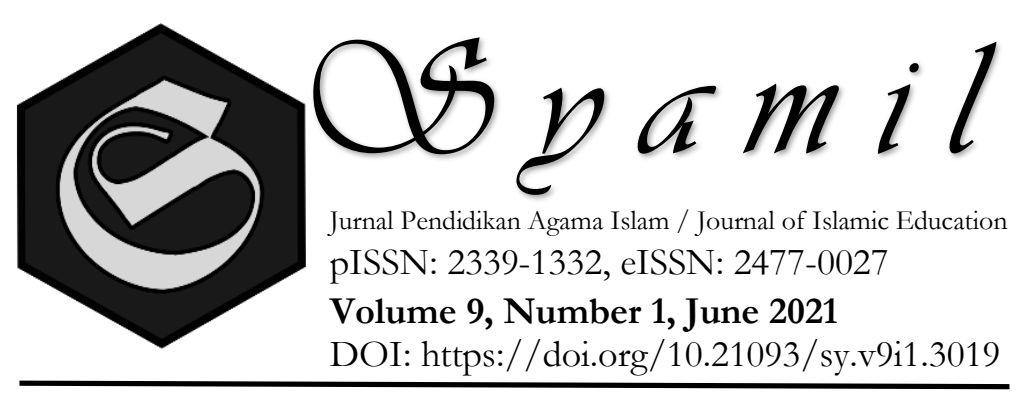

\title{
COMPARATIVE STUDY OF KUTTAB AND MADRASAH IBTIDAYAH EDUCATION SYSTEM
}

\author{
Fathurrahman Muhtar \\ Magister Pendidikan Agama Islam Pascasarjana UIN Mataram \\ Email: fathurrahmanmuhtar@uinmataram.ac.id
}

\begin{abstract}
This article shows the numerous benefits created in the 7th-13th century A.D. by a primary education institution named Kuttab. Kuttab is an educational institution that teaches the Qur'an to be read and memorized, history to be studied, and Arabic verses. This article utilizes an approach to literature research, gathering different references related to Kuttab. The empirical content process then evaluates the relation, and conclusions are drawn from the reference analysis. This paper concludes that with education in Madrasah Ibtidaiyah, Kuttab institutions have a similar curriculum. The excellence of Kuttab focuses more on memorizing the Qur'an so that in the golden age (712 years), Kuttab students will remember the entire material of the Qur'an, in addition to teachers who have excelled and skills. Unlike Ibtidaiyah madrasahs, which do not focus students on memorizing the Qur'an, and as teachers in Kuttab, teachers are also far from professionalism. In comparison to the current madrasah Ibtidaiyah curriculum, the learning materials in Kuttab are thin.
\end{abstract}

Keyword: Curriculum, Kuttab, Madrasah ibtidaiyah, teacher, Islamic education

\section{A. Introduction}

Islam is a religion that supports science, so if one lives in ignorance. Religion can tell that one's faith is not perfect. The first Quranic verse revealed a very transparent aspect in understanding education, namely the command to read for Allah's Messenger. This verse is included in the QS. Al-Alaq (96): 1 to 5. Islamic education is based on the educational messages of the Qur'an that encourage the development of a system of education and teaching by Prophet Muhammad SAW that has proven to produce influential Islamic leaders and generations. A great Muslim scholar with publications served as the theory and reference of the world in the past. 
The growth of Islamic science is seen from different periods, from the Daulah Umayyad, Abbasid, Fathimiyah, and Usmanid in the 4th century Hijriyah (10 to 14 Masehi) Influence seen in the development of civilization of nations in Western countries such as Spain and France over the following centuries. There are also Muslim poets who master various fields of science, such as philosophy. ${ }^{1}$

Educational excellence in the 7th-13th Hijriyah can produce a reliable and capable output compared to current Islamic education. Since the current portrait of Indonesian education has not shown the ideal goal humped by Article 3 No. 20 of 2003 of the National Education System Law stated that: national education serves to develop and form noble national character and civilization to educate the nation's life, aiming to create the potential for learners to become human beings who believe and believe in God Almighty. The purpose of national education is drawn a whole human figure to be built, both intact intelligence, spiritual and moral, emotional and aesthetic brilliance, intellectual and professional intelligence, as well as social and functional intelligence. ${ }^{2}$

However, the reality in the field shows that, in general, faith is not at heart or at the heart of the implementation of education. As a result, school graduates do not have the strong trust that can lead to multidimensional crises such as the current state of the nation, which basically lies in moral issues, including corruption, collusion, and nepotism, in part because of the low quality of faith in God.

As a result, madrassas are considered incapable of overcoming the moral crisis as part of the national education system. Education in madrasahs aims to foster people who believe and act correctly, as the purpose of Islamic religious education formulated by Indonesian Islamic thinkers and the Islamic world. Atiyah Al-Abrasy argues that Islamic Education aims to prepare people to live perfectly, happily, love the country, bind their bodies, perfect ethics (morals), orderly thoughts, subtle feelings, and proficiency in saying both verbally and in writing. While Marimba also argues that Islamic education is physical and spiritual guidance based on Islamic religious law that leads to the formation of the main personality in accordance with Islamic measures. ${ }^{3}$ Meanwhile, according to Ali Ashraf, it is argued that Islamic Education aims to train students' sensitivity in such a way that in their attitude to life, steps and decisions, so is their approach to all their knowledge governed by Islamic ethical values is very pronounced. ${ }^{4}$ Haidar Putra Daulay defines Islamic Education is an effort to develop all human potential both physically and mentally to form a full Muslim person ${ }^{5}$

${ }^{1}$ Mahmud, Pemikiran Pendidikan Islam (Bandung: Pustaka Setia, 2011), 188.

${ }^{2}$ Khaedar Natsir, Pendidikan Karakter Berbasis Agama Dan Budaya (Yogyakarta: Multi Presindo, 2013), 14.

${ }^{3}$ Ramayulis, Imu Pendidikan Islam (Jakarta: Kalam Mulia, 2002).

${ }^{4}$ Ali Ashraf, Horison Baru Pendidikan Islam (Pustaka Firdaus, 1989), 23.

${ }^{5}$ Haidar Putra Daulay, Pendidikan Islam dalam Perspektif Filsafat (Jakarta: Kencana Prenada Media, 2014), 11. 
The Kuttab educational institution, which teaches reading, memorizing and studying Arabic poems, emerged at the beginning of Islam's development. The subject matter of Kuttab bears the resemblance of the present Madrasah Ibtidaiyah. Kuttab, in his time, helped galvanize golden age children into students who were better prepared to attend higher education at that time, such as Halqa, Majlis-Majlis and Madrasah. Unlike today's Ibtidaiyah madrasah, which has become part of Indonesia's education system, it faces a number of challenges related to the quality of teachers, curriculum, facilities and infrastructure, and so on.

Among the various problems, such as the assumption that madrasahs are considered to be the same as public schools. Whereas madrasahs and schools have differences, as Abdurrahman Mas'ud explains, that madrasahs it mean school in the Indonesian language, but the meaning of attendance in the historical context of the struggle of the nation is not the same as school. If the school is generally known as an educational institution, the madrasahs come with their characteristics. Madrasah is the development of the oldest educational institution in Indonesia, known as pesantren. Pesantren is a historic-chronological madrasa with a cultural independence character in its historical perspective. ${ }^{6}$

In addition, according to Azyumardi Azra, the problem of madrasahs is still subject to discriminatory treatment. From a budgetary point of view, the Ministry of Religious Affairs is a vertical institution-which does not include decentralized-local governments and local parliaments (province, districts/cities are unable/unwilling to provide regular budgets to madrasahs), including additional incentives for madrasah teachers, even though madrasahs are educational institutions where the nation's children are also educated. ${ }^{7}$

In addition, Azyumardi Azra stated that Indonesia's Islamic education system is ranked among the most open and innovative education systems in the world, which is still less well known and realized by many in the Indonesian world of education, as well as by foreign observers and researchers. ${ }^{8}$ On this basis, in classical times, madrasahs were distinguished from madrasahs in Indonesia. The madrasah education system, especially Madrasah Ibtidaiyah in Indonesia, adopted the Kuttab education system in the golden era of Islam. The history of Madrasah Ibtidaiyah in Indonesia has no direct relationship with Kuttab education that developed in the classical Islamic era. According to Charles Michael Stanton, Madrasah in the classical Islamic era is a term of higher education institutions founded in 1064 under the protection of Nidham al-Mulk. The New Design,

${ }^{6}$ Abdurrahman Mas'ud, Antologi Studi Agama Dan Pendidikan (Semarang: Aneka Ilmu, 2004), 93.

${ }^{7}$ Azyumardi Azra, Pendidikan Islam: Tradisi Dan Modernitas Di Tengah Tantangan Milenium III (Jakarta: Prenada Media, 2012), 98.

${ }^{8}$ Azyumardi Azra, Pendidikan Islam:.. 100. 
called madrasah, uses the Khan Mosque as a model. Madrasahs can also be referred to as academies, as we know them today. ${ }^{9}$

Several studies discussed Kuttab, including Muhamad Idris, discussing the history of Kutab before madrasah. ${ }^{10}$ Emma Laisa explores the excellence of Kuttab, which is a strategic role in the efforts to establish the young generation of Islam in the classical era. Kuttab excels in religious and moral aspects and plays a role in improving intellectual and life skills ${ }^{11}$. It is therefore not surprising that Kuttab began to rise in Indonesia in 2012. This is based on the assumption that there are shortcomings in Islamic educational institutions or bad achievements. The success of Islamic education is achieved by obsessing over the teachings of the Prophet or by making it a model. ${ }^{12}$

According to several studies, basic education, particularly madrasah, has stalled as a result of a curriculum that does not meet the demands of society and community expectations. Furthermore, the educational system is underdeveloped, and the educational system is centered on the teacher (learning centre) ${ }^{13}$

State and private madrasah Ibtidaiyah are presented with a national curriculum framework that prioritizes broad topics above religious subjects, resulting in the concentric madrasah Ibtidaiyah. The budget for curriculum improvement in Madrasah Ibtidaiyah Negeri and the private sector is quite limited. Some elementary schools, such as Islamic Elementary School, aim to enhance education through a holistic education system in Sekolah Dasar Muhammadiyah that takes a cultural perspective. Bottom-up values, attitudes, and habits are regarded successful when they are based on the awareness and willingness of the school community. ${ }^{14}$ The development of such a system necessitates finance, which the stakeholder bears. As a result, it is not surprising that private Islamic primary schools in some areas are more expensive than Madrasah Ibtidaiyah Negeri, which still rely on government funding.

${ }^{9}$ Charles Michael Stanton, "Pendidikan Tinggi Dalam Islam, Terj. Afandi" (Jakarta: Logos, 1994), 101.

${ }^{10}$ Muhammad Idris, "Institusi Pendidikan Islam Sebelum Madrasah: Masjid Dan Kuttab, Jurnal Pendidikan Islam Tazkiya, Program Studi Pendidikan Agama Islam UIN Sumatera Utara," 2, 6 (2017).

${ }^{11}$ Emna Laisa, "Kuttab Sebagai Pusat Ilmu Pengetahuan Pendidikan Islam, Jurnal Pendidikan Agama Islam, Rabbani, IAIN Madura," 2, 1 (2020).

${ }^{12}$ Huswatun Hasanah and Ahmad Qodim, "Revitalisasi Pendidikan Kuttab Di Indonesia (Studi Kasus Kuttab al-Fatih), Prosiding Konferensi Ilmiah Mahasiswa Unissula (KIMU) 4 Universitas Islam Sultan Agung Semarang,” 2020.

${ }^{13}$ Hamdan, "The Imperativeness of Curriculum Improvement of Diniyah Education at the Wustha Level in South Kalimantan, Jurnal Dinamika Ilmu” Vol. 20, No. 1 (2020).

${ }^{14}$ Hendro Widodo, "The Role of School Culture in Holistic Education Development in Muhammadiyah Elementary School Sleman Yogyakarta, Jurnal Dinamika Ilmu” Vol. 19, No. 2 (2019). 
Even though madrasah has evolved into a distinctive feature of Islam, its quality remains below that of the institution as a whole. Some of the identified characteristics, such as educator factors, facilities, and money, have not altered considerably. ${ }^{15}$

\section{B. Method}

This research is a literature review using content analysis methods. The researchers' steps in this study were: first, selecting and identifying the subject and keyword problems. Second: collect various references related to the issue being studied. Third, classify data by subject. Fourth: data review and analysis. Fifth: conclusion. ${ }^{16}$

\section{Result}

\section{Kuttab: Children Education Institution}

Kuttab or Maktab two terms used in elementary institutions of the Islamic Classic Age; in Tarikh Baqdad's book, Kuttab popular in $238 \mathrm{H} / 852 \mathrm{H}$. The term al-Maktab is used from AD 282-283H/895-896. There are some differences in the use of this term as an al-Mubarak view that distinguishes Kuttab and Maktab. He mentioned that the Maktab was the name of the place where knowledge was taught. At the same time, Kuttab is the name of the institution. In Taj al Arus, the majority of experts referred to primary education as Kuttab. According to them, this is the most appropriate term than the term Maktab. ${ }^{17}$ Kuttab was the first major educational institution in the Islamic world. Kuttab initially took place in the house of the teachers and then in the mosques. Students Kuttab more and more so that Kuttab's educational activities are considered to interfere with worship activities in the mosque. Kuttab had a special place next to the mosque. ${ }^{18}$

Kuttab is the most authentic center of teaching among Muslims. Ahmad Syalabi mentioned that Kuttab had been in Arabia before Islam had arrived. ${ }^{19}$ Among the Makkah people who first learned to write Arabic letters were Sufyan bin Umayyad bin Abdi Shams and Abu Qais bi Abdi Manaf bin Zuhrah bin Kilab. These two men learned this from Bisyir bin Abdul Malik, who studied it in the 2009), 27.

${ }^{15}$ Haidar Putra Daulay, Pemberdayaan Pendidikan Islam Di Indonesia (Jakarta: Rineka Cipta,

${ }^{16}$ According to John W.Creswell, that library review means placing and concluding studies on a particular topic. These studies are often in the form of research studies John W. Cresswell, Research Desaign, Pendekatan Metode Kualitatif, Kuantitatif Dan Campuran, Terj. Achmad Fawaid (Yogyakarta: Pustaka Pelajar, 2016), 41.

${ }^{17}$ Munir ud Din Ahmed, Muslim Education and the Scholars Social Status (Zurich: Der Islam, 1968), 42.

${ }^{18}$ Hamdan Husein Batu Bara, "Kuttab Sebagai Potret Pendidikan Dasar Pada Masa Klasik, Dalam Jurnal Muallimuna," Volume 2, No. 1 (2016).

${ }^{19}$ Ahmad Syalabi, Sejarab Pendidikan Islam, Terj. Muchtar Yabya Dan Sanusi Latief (Jakarta: Bulan Bintang, 1973), 33. 
land of Hirah. ${ }^{20}$ In the first century, Kuttab's position was a priority, because it was the gateway to higher teaching. Kuttab visited the madrasahs of Ibtidiyah today. Ibn Hauqal founded 300 Kuttab in the town of Shaqilah. ${ }^{21}$

Well, according to A.L. Tibawi, initially before the Kuttab, teachers taught in their homes, where students needed them individually or in groups. But because of the teacher's request and the need to get the life of a formal servant. Teachers are passionate about accepting students in unique places, such as a room at home. The area was designated as a place of instruction known as Maktab or Kuttab, both terms derived from the Arabic word meaning "to write" The word Maktab is used in classical periods, while the word Kuttab is used in modern times. But both terms have been exchanged in Islamic history. ${ }^{22}$

Kuttab's goal is to ensure that Muslim children have the same rights in learning to read, write and memorize the Qur'an. Prophet Muhammad SAW is very concerned about the education of children and young people. He ordered prisoners of war to pay ransoms by teaching each person to teach ten children to write as a condition for his release. One day, Zaid ibn Tsabit taught ansar's children to write a letter to a group of worshippers. The urgency of reading and writing is very important for the Muslim community, as it relates to reports of revelations and as its juru juru. After Islam came, Kuttab not only taught reading and writing, but was equipped with the teachings of the Qur'an. In addition to other topics, this is the main subject. ${ }^{23}$

Kuttab, until the Abbasid era remained relevant as an educational institution, Kuttab, children were taught basic religious sciences, including reading and writing. Mahmud Yunus explained to Kuttab that the number of Kuttab and teachers taught children during the Abbasid (or Hijri) period and centuries later. There is one Kuttab in each area; There's even more than one Kuttab. There are about 300 Kuttab in the town of Balram in Shigilliah (Sicily). There are about 3000 students in Kuttab Abul Kasim al-Balkh. This proves that Kuttab has many teachers and students in it. ${ }^{24}$ Al-Hakam II opened several Kuttab elementary schools in Cordova and gave teachers his money. ${ }^{25}$ In Egypt, Kuttab is kept in towns and villages, while madrassas exist only in cities. AlAzhar's largest institution is in Cairo. ${ }^{26}$

${ }^{20}$ Haidar Putra Daulay and Nurgaya Pasha, Pendidikan Islam Dalam Lintasan Sejarah (Jakarta: Prenada Media Group, 2013), 87.

${ }^{21}$ Ragib As-Sirjani, Sumbangan Dunia Islam Pada Dunia (Jakarta: Pustaka Al-Kautsar, 2011), 203.

${ }^{22}$ A.L. Tibawi A.L. Tibawi, Islamic Education: Its Traditions and Modernization into the Arab National Systems (London: (London: Luzac And Company LTD, 1979), 33.

${ }^{23}$ A.L. Tibawi, Islamic Education:

${ }^{24}$ A.L. Tibawi, Islamic Education: 22.

${ }^{25}$ A.L. Tibawi, Islamic Education: 23.

${ }^{26}$ A.L. Tibawi, Islamic Education: 47. 
According to the date, the first art teacher in Kuttab came from Wadil Qura outside Medina on his way to Syria. The teacher lived and taught people who were interested in the art of writing. As far as written sources are concerned, use another book. This is to prevent students from using Verses of the Qur'an. Written learning materials are then removed at any time. ${ }^{27}$

Master Kuttab is known as al-Muallim, al-Mukattib, and al-Muaddib. The term Muaddib is a term for tutors who teach in the School of the Qur'an. At the same time, al-Mukattib and al-Muktib are designations for elementary school teachers. Muallim is a term of respect for the tuaest teacher in science, such as alKattan (198H/813-814), which states that no Muallim is alive except supyan bin Uyaina (198H/813-814M) a hadith expert and Junaid bin Muhammad (298H/910-911) the famous Sufi.

Students who have studied at Kuttab include Imam al-Bukhari (W $256 \mathrm{H}$ ), who completed his education in Kuttab when he was ten years old. He understood the books of Ibn Al-Mubarak (d. 181H) and Ibn al-Djarrah (d. 813$814 \mathrm{H})$ at the age of 16. Al-Isbahani $(\mathrm{d} .297 \mathrm{H})$ began writing his first book, Kitab al-Zahra, while still studying at Kuttab. Some students hear hadith for the first time when they are 4 to 6 years old or start memorizing the Qur'an when they are 5 years old. They listened to hadiths when they studied at Kuttab. Most children can write. The 9-year-old is already adept at writing hadiths with his hands. The most famous al-Kuttab in Baghdad included Kuttab al-Yatama (a school for poor children) and his teacher Ibn Haiyan. Ibn Sallam (d. 224 H) recounted that he taught children on the streets of Bisr and Bashir. Ibn al-Sikkim (d. 244) helped his father at a children's school in Harb al-Kantara. Al-Yazidi (d. $202 \mathrm{H}$ ) was the tutor son of Harun al-Rashid and Al-Ma'mun ${ }^{28}$

\section{Kuttab Education Objectives}

The main purpose of Kuttab education is in harmony with Islamic education, which is to foster the concept of God in the minds and souls of individuals. ${ }^{29}$ According to Omar Muhammad Taomy al-Syaibany, the purpose of Islamic education is to prepare the life of the world and the hereafter as the highest destination. Among the first to pursue this goal are Muslim educators who are aware of their religious nature, their high goals and tolerant principles, who need a balance between life in the world and the hereafter. Among the prominent characteristics in Islam is that Islam combines religion with Sharia, physical and spiritual, world and hereafter, forbids slavery, disapproves of the exile of a servant to worship, or isolates himself from society. Islam also invites people to work and produce, to consider human beings as young as his work. Islam rejects unemployment. Islamic teachings focus on the maintenance and

${ }^{27}$ Muhammad Athiyah Al-Abrasy, Prinsip-Prinsip Dasar Pendidikan Islam, Terj. Abdullah Zakiy al-Kaaf, ((Bandung: Pustaka Setia, 2003), 65: Pustaka Setia, 2003), 65.

${ }^{28}$ Munir ud Din Ahmed, Muslim Education and the Scholars Social Status, 46.

${ }^{29}$ Muhammad Hamid al-Afendi, Curriculum and Teacher Education (Jeddah: Hodder and Stoughton, 1980), 9. 
preparation of individual life, the world, and the hereafter. Islamic education in Islamic society pays attention to the education of children and youth in knowing religion, good character, not forgetting to establish religious teachings, including fasting, prayer, zakat, hajj and strengthening brotherhood and good relations between one person and another. Thus did those before them disbelieve in Allah, and do not harm them. In addition to religion and morality, Muslims pay attention to science and scientific research. How many Islamic scholars spend their lives learning, exploring, facing all difficulties because they see charity as a sacrifice in the way of God and science. ${ }^{30}$

The objectives of education, according to the International Conference on Education, are: education aims to strike a balance between the growth of the human personality as a whole and the balance achieved through the practice of the soul, the (intellectual) mind of the rational human self; feelings and senses. Therefore education must include human growth in all its aspects: spiritual, intellectual, imaginative, physical, scientific, linguistic, both individually and collectively, and push all these aspects towards good and perfection. The ultimate goal of Muslim worship is to achieve a perfect surrender to God both personally, in society and throughout mankind. ${ }^{31}$ Meanwhile, according to Muhammad Iqbal, the purpose of education is to create people. Thus, Iqbal, as contained in the verses of his poems, especially Asrar-i-Khudi, articulates the importance of self-improvement (Khudi). ${ }^{32}$ According to Naquib Al-Attas, the purpose of Islamic education is to create a universal or perfect human being (insanul kamil). According to him, every human being is a miniature kingdom, representing the microcosm (alamul shaghir) of macrocosm (al-alamul Kabir). He is a resident of the city itself, where he eats his dinner. Because in Islam, the goal of seeking knowledge at its peak is to be a good human being and not a resident of a good secular country, the education system in Islam must reflect the human being, not the state. ${ }^{33}$

\section{Kuttab Education Curriculum In Classic Times}

In the early days of Kuttab, the learning material provided consisted of reading and memorizing the Qur'an. Religious principles, writing, behaving like great people in Islam, reading and memorizing poetry, counting, Nahwu, and Sharef. This material is in line with Umar ibn Uqbah's message: Teach your children about Kitabullah and do not turn away from it. Teach saheeh and mutawattir hadiths, verses of science, and do not turn their attention to other sciences before they master the first knowledge. Because too much information

${ }^{30}$ Omar Mohammad al-Taumy al-Syaibani, Falsafah Pendidikan Islam (Jakarta: Bulan Bintan, 1979), 411.

${ }^{31}$ Ali Ashraf, Horison Baru Pendidikan Islam, 25.

${ }^{32}$ Wan Daud Mohd Nor, Filsafat Dan Praktek Pendidikan Islam Syed M. Naquib al-Attas (Jakarta: Mizan, 1998), 167.

${ }^{33}$ Syed Naquib Al-Attas, The Concept of Education in Islam: A Frame Work for an Islamic Philosophy of Education (Kuala Lumpur: ABIM, 1980), 85. 
various sciences have been received will complicate their understanding. Teach the life history of Islamic leaders and don't talk about women who smell sexuality. 34

Well, according to A.L. Tibawi, the study period of theory taken in Kuttab four years, the subject matter taught is an Arabic tradition such as arithmetic, history, geography and cleanliness. Advanced teaching materials include mathematics, physics, chemistry, biology, society, Getting to know the Turks, Francis, and Persians. The Girls School program is focused on household lessons, sewing and embroidery. ${ }^{35}$

Meanwhile, according to Charles Michael Stanton, the basic teaching method is to read and memorize the Qur'an and ancient poems. At first, students write their lessons on the sand with their fingers. Then clay sheets became popular, and with the influx of paper from the east in the eighth century, students were able to keep their records in the form of manuscripts. In the context of a long oral tradition, education encourages students to memorize the Qur'an and as many other subjects as possible. ${ }^{36}$

In the history of Islamic education, there are two types of Kuttab. The first is a place that can teach reading and writing basic texts of Arabic poetry, and most teachers are non-Muslims (in the early moments). The second type of Kuttab is a place to teach the Qur'an and the basics of Islamic teaching. The Prophet (peace and blessings of Allaah be upon him) ordered al-Hakam ibn Sa'id to teach at Kuttab in Medina. The children sit in circles around the teacher called the halaqah system. The learning system of salaf (traditional) methods, before the modern approach, was known as the classical system through the madrasah system. The level of education in Kuttab, divided into two classes, namely: first: Kuttab Awwal: at this level, children learn to read, write, memorize the Quran, basic religious sciences, and calculate the basis of Kuttab Qonuni: at this level, children and adolescents learn the science of language and Adab. They studied religious science, hadith, and special skills (farming and trading). ${ }^{37}$

They also obtained information about the subject matter needed by Hisyam Bin Abdul Malik, who instructed his son's teacher to pay attention, memorize, and study the Qur'an. They also teach good poems, so that their children have a sense and feel that they are contained in poetry, namely that they have a beautiful and wise right. Then he also made a willingness to invite his children to look around arab life and to be able to take their good verses to be studied and understood, to know what is forbidden and allowed by God. So that

${ }^{34}$ Muhammad Atiyah Al-Abrasy, Beberapa Pemikiran Pendidikan Islam, Terj. Syamsuddin Asyron (Yogyakarta: Aditya Media, 2012), 62.

${ }^{35}$ A.L. Tibawi, Islamic Education, 67.

${ }^{36}$ Charles Michael Stanton, Pendidikan Tinggi Dalam Islam,.., 22.

${ }^{37}$ Muhammad Idris, "Institusi Pendidikan Islam Sebelum Madrasah: Masjid Dan Kuttab , Jurnal Pendidikan Islam Tazkiya, Program Studi Pendidikan Agama Islam UIN Sumatera Utara, Volume 6 Nomor 2, 2017," n.d. 
the teachings of religion can be carried out correctly. In addition, he focused on his son's teacher always encouraged him to learn the type of khutbat (talk) with deep wisdom, strong point of view, valuable message, high rhetorical style, and other good speech values.

Ibn Sina had a well-known opinion on the education of children. Ibn Sina's view of the first level curriculum in Islamic education can be stated as follows: first, the child must learn the Qur'an, of course, when the child is physically and mentally ready to learn. At the same time, he must also understand the alphabet, teach the basics of religious education, and learn poetry, starting with selected poems containing ethical virtues. In addition, appreciation of science, reproach for ignorance, encouragement to both parents to do good, to do good deeds, to serve guests well, and to become the primary material for children's educators. ${ }^{38}$

While visiting Damascus in 1184, bin al-Jubayr discovered that children had acquired writing skills by referring to ancient Arabic poems, not the Qur'an, because they believed that the act of memorizing the sentences of God was considered insulting and degrading to Him. In addition to reading and learning Arabic grammar, the stories of the Prophets-especially the hadiths of Prophet Muhammad SAW - were the basics of arithmetic, and they also studied poetry on the condition that it was not erotic. The memorization method is essential in almost all curricula taught. Usually, the best students in Kuttab will have the honor of joining the parade. They rode camels, walked the streets of the city, and they threw almonds at them. ${ }^{39}$

According to Armai Arief, Kuttab's curriculum in classical times shows the following: 1) Although Kuttab has been around since pre-Islam and its first goal of learning to read and write, then the teaching of the Qur'an has become an essential theme of Kuttab's study. Of course, reading the Qur'an not only meets the cognitive aspect, but is designed to meet the perspective aspect so that children can appreciate the values of the Qur'an. 2) The issue of moral education is very important because it is the realization of the message of the Qur'an. Educational institutions meant moral guardian institutions at that time. Moral transgression is a gross violation, so generally, all lessons, especially religious lessons, always contain honest content. 3) Art classes, such as dance and music, are not developed in Kuttab. Perhaps this kind of art is feared to undermine the child's morality. 4) Other lessons outside the Qur'an class, such as Arabic grammar, can be given as a medium to understand the Qur'an 5) Sports assignments and calculations have not yet been given a detailed picture of how the material and its implementation in Kuttab are performed. 6) No lessons can

${ }^{38}$ A.L. Tibawi, Islamic Education, 192

39 Philif K.Hitti, History of The Arab, Terj.R. Cecep Lukman Hakim, Dkk (Jakarta: PT.Serambi Ilmu, 2005), 512. 
be used as a basis for the development of science in the next generation of education. ${ }^{40}$

Ibn Khaldun hinted at the importance of memorizing the Quran for children. He explained that teaching the Qur'an is a shared education in all school teaching plans in different Islamic countries, because teaching the Qur'an is an Islamic teaching that will lead to a stronger faith than a person.

Muhammad Athiyah Al-Abrasi mentions some of the specificities of the following classical Islamic century learning plan: 1. Lead the lesson plan, especially in the area of religion. Children learn to read, to write, to memorize the Qur'an and to get to know the commons of Islam, 2. The issue of moral and moral education is dealt with once. Muslim educators have been successful in this field and have left long traces of Islamic teaching, 3. If, in the past, Muslims have given priority to religious and moral aspects, they have not forgotten the practical elements and uses of curricula such as poetry lessons, languages, useful proverbs, counting, history, swimming, archery, and sports, 4. In the past, Muslims were concerned about giving subjects about the beauty of art to children. They assume that seductive music, images, dances, and romantic speech undermine children's morals. ${ }^{41}$

The curriculum of the maktab as stated earlier center around the Quran and the child was thought to read it and learn it by heart. He also learnt to read, write and calculate and in some areas of the Muslim world was taught Arabic language and literature so as enhance his appreciation of the Holy Quran and the Tradition of the Prophet. A great deal of the learning had to be by rota involving drills and repetition, sometimes at the expense of understanding. Once the Holy Book and a fair number of Hadis had been mastered the student was involved in courses of exegesis and scholarly elaboration of the tradition. ${ }^{42}$

\section{Curriculum In Madrasah Ibtidaiyah.}

Prior to the twentieth century, the Islamic Education tradition in Indonesia did not recognize the name madrasah, with the exception of the recitation of the Quran, mosques, pesantren, surau, langar, and tajuq. With the establishment of madrasah Manbaul Ulum Surakarta kingdom in 1905 and Adabiyah school in West Sumatra by Sheikh Abdullah Ahmad in 1909, the madrasah entered the twentieth century. During the Dutch colonial period, madrasahs were not organized into a single entity. Every madrasah appears in its own unique way. ${ }^{43}$

${ }^{40}$ Armai Arief, Sejarah Pertumbuhan Lembaga-Lembaga Pendidikan Islam Pada Masa Klasik. (Bandung: Angkasa, 2014), 143.

${ }^{41}$ Muhammad Athiyah Al-Abrasy, Prinsip-Prinsip Dasar Pendidikan Islam, 172.

${ }^{42}$ M.A. Zaki Badawi, "Traditional Islamic Education-Its Aim and Purposes in the Present Day," in Aims And Objectives of Islamic Education, Syed Mubammad al-Naquib al-Attas (Ed) (Jeddah: Hoddler and Stughton, 1978), 108.

${ }^{43}$ Mujammil Qomar, Pesantren Dari Transformasi Metodologi Menuju Demokratisasi Institusi (Jakarta: Erlangga, 2007), 91. 
Madrasah arose as a result of a variety of factors, including both internal and international networks, particularly in the Middle East. Domestic demands in the form of Islamic revivalism in the final decades of the nineteenth century, as well as the adoption of Dutch Education to actualize ethical politics While the Middle East is based on the influence of Makkah, Baghdad, and Egypt, the Middle East network is based on the influence of Makkah, Baghdad, and Egypt. Due to the introduction of pilgrims and Kiai who initially studied in the Prophet Muhammad's homeland, the influence of Madrasah Dar al-Ulum and Shaulatiyah expanded to Madrasah in Pesantren. ${ }^{44}$

Madrasah can be interpreted as a school in a religious learning process. In this case, madrasah Ibtidaiyah is a primary education provider who has a key role to play in enabling children and making them a useful member of society and making children happy to do good. In Law No. 20 of 2003 of the National Education System, Chapter X, Article 37, paragraph 1, it was explained that the curriculum of primary and secondary education must include religious education. 45

Today, the 2013 curriculum in madrasa uses an integrated thematic, scientific approach, as well as an authentic assessment. Integrative thematic is the fusion of several subjects into one theme. The scientific method is the approach of asking, trying, and reasoning. At the same time, authentic assessment is an assessment that measures all powers of attitude, skill and knowledge based on process and results.

According to Tholhah Hasan, the curriculum of religious education is still dogmatic and informative. It therefore takes the creativity and dedication of spiritual teachers to teach all their students the universal values of religion. The extent of the practice of spiritual teaching taught in schools is also a measure of the success of religious education in schools. In reality, however, the various studies and research conducted by the Center for Research and Development of Religious and Religious Education on the implementation of religious education in schools have not significantly correlated with the behavior of students in holy obedience. These findings suggest that religious education in schools has not been effective. The indicator is that students who obtain high scores of religious education do not show obedience to spiritual teaching. ${ }^{46}$

The Curriculum Structure of Madrasa Ibtidaiyah refers to the Guidelines of the Decree of the Minister of Religious Affairs, Guideline 184 of 2019. The decision to divide groups A and B. Group A consists of Islamic education subjects, including the Coran Hadith, Akidah Akhlak, Fikih, Islamic Civilization History, PPKN, Bahasa Indonesia, Arabic, Mathematics, Science and Social

\footnotetext{
${ }^{44}$ Mujamil Qomar, Pesantren Dari Transformasi, 42.

45 "Undang-Undang Nomor 20 Tahun 2003 Sistem Pendidikan Nasional, Bab X, Pasal 37, Ayat 1".

${ }^{46}$ Muhaimin, Pemikiran Dan Aktualisasi Pengembangan Pendidikan Islam. (Jakarta: Rajawali Pers, 2011), 158.
} 
Sciences. Group B is made up of cultural arts and pre-employment lessons, physical education, sports and health, and local content.

When referring to the curriculum referred to above in Islamic studies, it is similar to the curriculum developed by Kuttab in the classical century. Islamic education curricula developed in Kuttab are dominated by religious sciences, especially the Coran as the focus of teaching, as well as the present, but nowadays all material or religious sciences are interlinked and support each other's graduation students. In the process of development, the Islamic education curriculum in madrasa Ibtidaiyah is more detailed and comprehensive than the curriculum in Kuttab. Problems with the application of current curricula, such as the issue of professionalism and the competence of teachers to develop curricula, are still far from expected, compared to the professionalism of Kuttab teachers in the 7th-13th century A.D.

Qualitatively, the quality of madrasah graduates is still considered to be very low; this is due to the low quality of teachers due to a number of factors. First of all, there's a mismatch. Teachers do not follow their fields. For example, Tarbiya Islamic Education Graduate Teachers teach Indonesian subjects. Teachers are not graduates of mathematics teaching mathematics subjects, and in some places graduates of the sharia faculties teach mathematics subjects. Secondly, the quality of prospective teachers. For a long time, the teaching profession has not been very attractive to young people who are smart or intelligent because their appreciation is low compared to other occupations. Third, graduates who have not qualified as teachers of madrasah. Most teachers still qualify for S1, when compared to developed countries, their education requires Master's degree teachers. ${ }^{47}$

There are also Ibtidaiyah madrasahs, which have advantages, such as Madrasa Ibtidaiyah Negeri (MIN) 1 Malang. This madrasah is the best madrasah in East Java as a pilot project and model school in Indonesia and several Middle Eastern and African countries. ${ }^{48}$ These advantages are undoubtedly influenced by the professionalism of human resources in madrasahs.

Competence and professionalism that must belong to Islamic education teachers that are rarely found today, as conveyed by Muhammad Athiyah AlAbrasi, namely the four personalities that must be owned by an educator, are as follows: 1. In Islam, a teacher has a high and holy place, so he must know his obligations as a teacher. He must be real, Zuhd. He also teaches us to seek God's way, not to seek wages, salaries, or money in return, 2. The teacher must cleanse his body, away from sin and error, cleanse the soul, avoid major sins, ria (search for names), spite, hostility, strife, and other irritating traits, 3. Honesty of a teacher in his work is the best way to succeed the implementation of the duties and

${ }^{47}$ Sutrisno and Suyatno, Pendidikan Islam Di Era Peradaban Modern (Jakarta: Prenada Media, 2015), 52.

${ }^{48}$ Azyumardi Azra, Pendidikan Islam: 89. 
success of his students, 4 . The teacher must forgive his students. He can restrain himself, hold back anger, be patient, be patient, not grumpy because of small things, personality, and self-esteem. ${ }^{49}$

Al-Farabi said the teacher was like a house in front of the students. Therefore, teachers must have the following criteria: 1 . Have perfect health and limbs that can easily support the implementation of its functions and various potentials in a balanced way, 2. Have perfect intelligence that allows him to serve intensively as a speaker (teacher) in different situations and environments, 3 . Has a good memory so that he can remember what he had in mind, everything he has understood, seen, heard, and received, 4. Have a wisdom and a real impact on understanding that allows students to re-present the material, 5. Has an eloquent speaking ability so that his tongue can help him to express his mind in perfect form, 6. Devote yourself fully to education and teaching, willing to receive knowledge quickly and without interruption, 7 . Have a friendly attitude towards the truth expressed by a person and avoid false things, 8. Be big-hearted, love glory and greatness will be without any healing, 9. Devote yourself to justice and hate injustice, and 10 . Has a strong capacity to overcome problems, courage, and timeliness. ${ }^{50}$

\section{Discussion}

The goal of Kuttab Education and Madrasah Ibtidaiyah Education is the same. However, when contrasted to today's madrasah education system, Kuttab education had an edge in classical times. Madrasah now has to deal with a dualist education system that combines religious and public education. Madrasah's characteristics will be lost if you follow the public education system. Similarly, if you follow a different system, you will be at a disadvantage in comparison to secular educational institutions.

This is the case in Egypt and some other Arab and non-Arab countries. In those countries one type of education starts at the primary stage with special curricula, and ends with Colleges of Islamic and Arabic education. The graduates of this type education usually work as teacher, mosque Imams, or preachers. The other type of education is secular education which follows a different kind of curriculum from primary up to university level. The graduates of this type of education take miscellaneous jobs except for those which are allotted to graduates of Islamic university. ${ }^{51}$

Duality in this sense has its supporters and its opponents and each group has strong reason for taking sides. The advocates of duality claim that every

${ }^{49}$ Muhammad Athiyyah al-Abrasyi, Prinsip-Prinsip Dasar Pendidikan Islam, 147-149.

${ }^{50}$ S.M.Zianuddin Alavi, Pemikiran Pendidikan Islam Pada Abad Klasik Dan Pertengahan (Bandung: Angkasa, 2003), 83.

${ }^{51}$ U. A. AL-Beely, "The Islamic Concept of Educational Curricula, in 'Curriculum and Teacher Education' Muhammad Hamid al-Efendi and Nabi Ahmed Baloch, (Ed) Jeddah: Hodder and Stoughton King Abdul Aziz University, 1980), 22 
Muslim Country is keen to keep abreast of material progress, and to attain parity in standard with advanced countries in such areas as industry, civilization and modern technology. They also claim that there is no way to attain such standard except by training specialist in physical science, industry, the art and humanities.

To increase the standard of madrasah quality in H. A. Mukti Ali period as the minister of religion proposes a to madrasah improvement quality with the SKB 3 Menteri policy, which aims to aims to align the quality of madrasah with non-madrasah with a 70 per cent general and 30 per cent religious component. In the Munawir Sadzali period, as the minister of religion, proposed the notion of MAPK. In contrast, Tarmizi Taher as the minister of religion, proposed madrasah as a public school distinguished by the Islamic religion. These policies do not elevate the madrasah. The portion of $70 \%$ of general knowledge and $30 \%$ of religious knowledge is understood symbolically-quantitatively and not substantially qualitatively, so output mastering knowledge is not maximal as well as spiritual knowledge. ${ }^{52}$

Kuttab in some countries are traditional education. The core subject in Kuttab education was the Holy Qur'an. The study of the Qur'an was the preoccupation of the traditional school from the very moment that it come into being. The educational of the Muslim child began with the Holy Book which he learns to read, recite and memorize. The holy Quran is the final guide for the Muslim in matters of basic beliefs, form of worship and rules of conduct. From the study of the Quran, the student develops his knowledge of Islam and derives his moral idea.

Madrasah, as compared to Kuttab, a traditional Islamic education system that only teaches religious subjects. Madrasah arose from Pondok Pesantren in Nusantara with a different methodology and a diff historical background. The madrasah system differs from the school system in its growth. Pondok Pesantren is a traditional education system-preserving institution. Madrasah, on the other hand, responds to numerous changes that occur in order to become a more modern Educational Institution in terms of technique and teaching curriculum. To compete, Madrasah must implement strategic improvements in the field of management strategy.

Kuttab education is considered to have produced qualified graduates in the past. On the other hand, Madrasah Ibtidaiyah education is believed to be unable to compete with school educational institutions. The government has made many efforts to improve the competitiveness of madrasas, but madrasah remains the second most important educational institution after school education. Even today, there are integral Islamic basic educational institutions. Competitor's madrasah has a learning system that emphasizes memorizing alQur'an and Hadith of the Prophet as the Kuttab Institute once used the system.

${ }^{52}$ Muhaimin, Pengembangan Kurikulum Pendidikan Agama Islam Di Sekolah, Madrasah Dan Perguruan Tinggi (Jakarta: Rajawali Pers, 2005), 198. 
Madrasah education is a type of Islamic education. The low quality of teachers is one of the key reasons for the low quality of madrasah graduates. The low quality of teachers is due to a number of factors. To begin with, there is a mismatch: the teaching teacher is not on the job. Instructors from the Tarbiyah Faculty of Islamic Education, for example, teach Bahasa Indonesian disciplines, and teachers who are not mathematics graduates teach mathematics subjects, despite the fact that shari'ah graduates teach mathematical lessons. The second factor is the caliber of potential teachers. Because of the low pay, teaching has traditionally been a less appealing career to bright and talented young people. Graduates in teaching, like undergraduates, get very low earnings when compared to other professions or jobs. Third, graduates who are not qualified to teach in madrasahs. The majority of madrasah teachers are undergraduates.

In any country that establishes its education, the absolute requirement to be a teacher is a Master of Education, not a general education master, but a master in the field of studies, such as an of Mathematics Education, a master of English Language Education, or a master of Indonesian Language Education.

\section{E. Conclusion}

The Islamic educational institution Kuttab has been shown to educate children of golden age to become Muslim scholars who have skills that are not widely found in this era. Kuttab focuses students on memorizing the entire contents of the Qur'an at an early age when compared to madrasah Ibtidaiyah educational institutions that do not emphasize memorization of the Qur'an. The curriculum developed by Kuttab can not be separated from the situation and condition of Muslims in the past. Unlike the current madrasah Ibtidaiyah, which is heavily influenced by the current situation and needs of globalization, it requires students to master religious science, and technological science. Also, the professionalism of Ibtidaiyah madrasah teachers needs to be improved if they want the quality of Ibtidaiyah madrasahs today, because the quality of teachers also determines the quality of Kuttab education in classical times. 


\section{BIBLIOGRAPHY}

Ahmed, Munir ud Din. Muslim Education and the Scholars Social Status. Zurich: Der Islam, 1968.

A.L. Tibawi, A.L. Tibawi. Islamic Education: Its Traditions and Modernization into the Arab National Systems (London: London: Luzac And Company LTD, 1979.

Al-Abrasy, Muhammad Athiyah. Prinsip-Prinsip Dasar Pendidikan Islam, Terj. Abdullab Zakiy al-Kaaf,. Bandung: Pustaka Setia, 2003.

Al-Abrasy, Muhammad Atiyah. Beberapa Pemikiran Pendidikan Islam, Terj. Syamsuddin Asyron. Yogyakarta: Aditya Media, 2012.

Al-Attas, Syed Naquib. The Concept of Education in Islam: A Frame Work for an Islamic Philosophy of Education. Kuala Lumpur: ABIM, 1980.

Alavi, S.M.Zianuddin. Pemikiran Pendidikan Islam Pada Abad Klasik Dan Pertengahan. Bandung: Angkasa, 2003.

Arief, Armai. Sejarah Pertumbuban Lembaga-Lembaga Pendidikan Islam Pada Masa Klasik. Bandung: Angkasa, 2014.

Ashraf, Ali. Horison Baru Pendidikan Islam. Pustaka Firdaus, 1989.

As-Sirjani, Ragib. Sumbangan Dunia Islam Pada Dunia. Jakarta: Pustaka Al-Kautsar, 2011.

Azra, Azyumardi. Pendidikan Islam: Tradisi Dan Modernitas Di Tengah Tantangan Milenium III, Jakarta: Prenada Media, 2012.

Cresswell, John W. Research Desaign, Pendekatan Metode Kualitatif, Kuantitatif Dan Campuran, Terj. Achmad Fawaid. Yogyakarta: Pustaka Pelajar, 2016.

Daulay, Haidar Putra. Pendidikan Islam Dalam Perspektif Filsafat. Jakarta: Kencana Prenada Media, 2014.

Hamid al-Afendi, Muhammad. Curriculum and Teacher Education. Jeddah: Hodder and Stoughton, 1980.

Hasanah, Huswatun, and Ahmad Qodim. "Revitalisasi Pendidikan Kuttab Di Indonesia (Studi Kasus Kuttab al-Fatih), Prosiding Konferensi Ilmiah Mahasiswa Unissula (KIMU) 4 Universitas Islam Sultan Agung Semarang," 2020.

Idris, Muhammad. "Institusi Pendidikan Islam Sebelum Madrasah: Masjid Dan Kuttab , Jurnal Pendidikan Islam Tazkiya, Program Studi Pendidikan Agama Islam UIN Sumatera Utara, Volume 6 Nomor 2, (2017)

K.Hitti, Philif. History of The Arab, Terj.R. Cecep Lukman Hakim, Dk.k. Jakarta: PT.Serambi Ilmu, 2005. 
Laisa, Emna. "Kuttab Sebagai Pusat Ilmu Pengetahuan Pendidikan Islam, Jurnal Pendidikan Agama Islam, Rabbani, IAIN Madura," 2, 1 (2020).

Mahmud. "Pemikiran Pendidikan Islam .," 188. Bandung: Pustaka Setia, 2011.

Mas'ud, Abdurrahman. Antologi Studi Agama Dan Pendidikan. Semarang: Aneka Ilmu, 2004.

Mohammad al-Taumy al-Syaibani, Omar. Falsafah Pendidikan Islam. Jakarta: Bulan Bintan, 1979.

Mohd Nor, Wan Daud. Filsafat Dan Praktek Pendidikan Islam Syed M. Naquib al-Attas. Jakarta: Mizan, 1998.

Muhamin. Pemikiran Dan Aktualisasi Pengembangan Pendidikan Islam. Jakarta: Rajawali Pers, 2011.

- Pengembangan Kurikulum Pendidikan Agama Islam Di Sekolah, Madrasah Dan Perguruan Tinggi. Jakarta: Rajawali Pers, 2005.

Natsir, Khaedar. Pendidikan Karakter Berbasis Agama Dan Budaya. Yogyakarta: Multi Presindo, 2013.

Putra Daulay, Haidar. Pemberdayaan Pendidikan Islam Di Indonesia. Jakarta: Rineka Cipta, 2009.

Putra Daulay, Haidar, and Nurgaya Pasha,. Pendidikan Islam Dalam Lintasan Sejarah. Jakarta: Prenada Media Group, 2013.

Qomar, Mujammil. Pesantren Dari Transformasi Metodologi Menuju Demokratisasi Institusi. Jakarta: Erlangga, 2007.

Stanton, Charles Michael. Pendidikan Tinggi Dalam Islam, Terj. Afandi, Jakarta: Logos, 1994.

Sutrisno, and Suyatno. Pendidikan Islam Di Era Peradaban Modern. Jakarta: Prenada Media, 2015.

Syalabi, Ahmad. Sejarah Pendidikan Islam, Terj. Muchtar Yabya Dan Sanusi Latief. Jakarta: Bulan Bintang, 1973.

U. A. AL-Beely. "The Islamic Concept of Educational Curricula, in 'Curriculum and Teacher Education' Muhammad Hamid al-Efendi and Nabi Ahmed Baloch, (Ed) (Jeddah: Hodder and Stoughton King Abdul Aziz University, 1980), 22." In Curriculum and Teacher Education" Muhammad Hamid al-Efendi and Nabi Abmed Baloch, (Ed), 22. Jeddah: Hodder and Stoughton King Abdul Aziz University, 1980.

"Undang-Undang Nomor 20 Tahun 2003 Sistem Pendidikan Nasional, Bab X, Pasal 37, Ayat 1," n.d. 
Widodo, Hendro. "The Role of School Culture in Holistic Education Development in Muhammadiyah Elementary School Sleman Yogyakarta, Jurnal Dinamika Ilmu" 19, no. 2 (2019). 